\title{
Farklı Öğretmenlik Programına Devam Eden Öğretmen Adaylarının Öğretmenlik Mesleğine Yönelik Algıları
}

\author{
The Perceptions of Teacher Candidates from Different \\ Programs on Teaching Profession
}

\author{
Figen ÇAM TOSUN**, Arslan BAYRAM***
}

\begin{abstract}
Öz: Nitel araştırma yöntemlerinden olgubilim deseniyle tasarlanan bu araştırma, Eğitim Fakültesi 1. ve 4. Sınıf öğrencileriyle pedagojik formasyon alan öğrencilerin öğretmenliğin uzmanlık gerektiren bir meslek olup olmadığına yönelik görüşlerini ortaya çıkarmayı amaçlamaktadır. Bayburt Eğitim Fakültesi 1. ve 4. Sınıf öğrencileriyle 2014-2015 güz döneminde pedagojik formasyon alan öğrencilerin öğretmenliğin uzmanlık gerektirip gerektirmediği konusundaki görüşlerini ortaya çıkarmak için nitel araştırma yöntemi kullanılmıştır. Araştırmanın çalışma grubunu, 2014-2015 öğretim yılında Bayburt Eğitim Fakültesi 1. (67) ve 4. Sınıf (75) öğrencileriyle yine bu dönemde pedagojik formasyon alan (75) öğrenciler oluşturmaktadır. Araştırmacılar tarafından öğrencilerin öğretmenliğin uzmanlık gerektirip gerektirmediği konusundaki öznel değerlendirmelerini alabilmek için öğretmenlik ve uzmanlaşma konusu ile ilgili 9 sorudan oluşan bir görüşme formu hazırlanmıştır. Araştırmaya katılan öğrenciler uzmanlaşmayı olumlu karşılarken, öğretmenlik mesleğinin bir uzmanlık alanı olduğunu ifade etmektedirler. Eğitim fakültesi öğrencileri farklı fakültelerden mezun olanların öğretmen olarak atanmasına karşı çıkarken pedagojik formasyon öğrencileri doğal olarak bu eğitimi aldıktan sonra öğretmen olarak atanmanın doğru olduğunu düşünmektedirler. Pedagojik formasyon kaldırılmalı ve yalnızca Eğitim Fakülteleri öğretmen yetiştirmelidir.
\end{abstract}

Anahtar Kelimeler: Öğretmenlik mesleği, uzmanlaşma, eğitim fakültesi

\begin{abstract}
Current study was designed with phenomenological method of qualitative research methods, which aims to reveal the perspectives of 1st and 4th year students of Education Faculty and pedagogical training students on whether teaching profession requires expertise. Qualitative research methods were used to reveal participants' views on whether teaching profession requires expertise. The data were collected in 2014-2015 fall term. The study group consists of 1st year students (67) and 4th year students (75) of Bayburt Education Faculty, and pedagogical training students (75). Purposeful sampling was used because 1st year students has met teaching profession recently, 4th year students will graduate and pedagogical training students were selected as they are suitable for appointment. Descriptive analysis technique was used to analyse qualitative data which were obtained from interviews. Additionally, percentage and frequency of responses were calculated. Students express that they have positive views about specialization and teaching profession is an expertise. As education faculty students object to appointment of other faculties' graduate as teacher, pedagogical formation students think that it is appropriate after they have completed the training.
\end{abstract}

Keywords: Teaching profession, expertise, faculty of education

\section{Giriş}

Bilginin hızla çoğaldığı ve yayıldığı günümüzde meslekleri icra edenler bütün bilgiye sahip olamadıkları için bilim alanlarını bölümlere ayırarak daha küçük alanlarda bilgiye hakim olmaya çalışmaktadırlar. Bu bağlamda ortaya çıkan Uzmanlaşma kavramı, örgüt içindeki meslek başlıklarının veya yerine getirilmesi gereken işlevsel faaliyetlerin farklılığı ve işlevsel faaliyetleri yerine getirebilmek için gerekli eğitimin niteliği (Hage, 1965; Robbins, 1983, 46; Dalton vd., 1980); çeşitli işlevler için biçimsel iş tanımlarında ayrıntılarıyla açıklanmış, oldukça

\footnotetext{
*VI. Uluslararası Eğitim Yönetimi Forumunda Öğrenci Bakışıyla: Öğretmenlik Uzmanlık Gerektirir mi? Başlığı altında sözlü olarak sunulmuștur.

**Yrd. Doç. Dr., Bayburt Üniversitesi, Eğitim Fakültesi, Bayburt-Türkiye, e-posta. figencam@gmail.com

***Yrd. Doç. Dr., Artvin Çoruh Üniversitesi, Eğitim Fakültesi, Artvin- Türkiye, e-posta. arbay06@hotmail.com
} 
özelleştirilmiş gerekliliklerin derecesi (Robbins, 1983, 46) veya işbölümü sonucunda oluşan görevler (pozisyonlar) konusunda gerekli yeterli bilgi ve beceriyle donanmak (Sucu, 2000) olarak tanımlanmaktadır.

Uzmanlaşmayı İktisat Terimleri Sözlüğü, ülkelerin, bireylerin veya örgütlerin üretime yönelik çabalarını, yeteneklerini ve bilgilerini çok sayıda alandan ziyade sınırlı bir alanda yoğunlaştırarak verimliliklerini artırması (TDK, 2015) şeklinde tanımlamıştır. Toplumbilim Terimleri Sözlüğü ise örgensel, coğrafyasal, üretimsel, kurumsal vb. özellikler ve koşullar sonucu oluşan ve yol, yordam, bilgi, beceri konularında toplumsal işbölümü ve ayrımlaşmaya götüren süreç (TDK, 2015) olarak tanımlamaktadır.

Weber "Bürokrasi Modeli”ni açılklarken uzmanlaşmaya büyük önem vermiştir. Weber'e göre bürokrasiden yarar sağlayabilmek için işler uzmanlaşmış kişiler tarafından yürütülmelidir. Uzmanlaşma, hız ve etkinlik sağlar. Uzmanlaşmayı sağlamak için de işlerin en üst seviyede kategorileştirilmesi ve bölümlere ayrılması gerekmektedir. $\mathrm{Bu}$ durumda birey, mesleğin gerektirdiği uzmanlık bilgilerini, eğitim ve tecrübe ile kazanmış ve uzmanlaşmıştır

Weber'e (Akt: Şeker, 2014).göre organizasyondaki çalışanların yetenekli ve tecrübeli oldukları alanlara göre dağıtılması ve buna göre işbölümü yapılması hedeflenir. Örneğin satış bölümünde çalışanlardan birisinin, şehrin doğu bölgesinde tecrübesi varsa, bu çalışanın bu bölgede istihdam edilmesi gerekir

Bazı bilim insanları bireylere yeteneklerinden daha iyi yararlanma imkânı verdiği için toplam üretimi artırmak gibi bir etkisi olduğu için uzmanlaşmanın gerekliliğini savunurken (Gwartney ve Stroup, 2004) bazı bilim insanları (Bursalığlu, 1982; Ercan, 2002) da uzmanlaşmayı bazı nedenlerle eleştirmektedir. $\mathrm{Bu}$ eleştiri noktalarından biri, bilgi ve yeteneklerin sınırlı bir alanda geliştirilmesidir, bu durum örneğin kardiyolog olan bir doktorun sadece kalp hastalıklarını bilmesine neden olmaktadır. Diğer bir eleştiri ise toplumsal iş bölümünde ayrımlaşmaya götürdüğü içindir.

$\mathrm{Bu}$ araştırmada uzmanlaşma kavramı, bir bilim kolunda özel ve derin bilgisi olma durumu, uzman da belirli bir programda yeterlik kazanmış olan kimse (Duman, 1988) bağlamında ele alınmıştır. Uzmanlaşmanın ve uzmanın bu anlamlarından yola çıkarak öğretmenlik mesleği ile ilgisi kurulmaya çalışılmıştır.

Milli Eğitim Temel Kanunun (1739 sayılı kanun) 43. maddesinde öğretmenlik mesleği tanımlanmıştır. Buna göre "Öğretmenlik, Devletin eğitim, öğretim ve bununla ilgili yönetim görevlerini üzerine alan özel bir ihtisas mesleğidir" (madde 43). Uzmanlık alanıyla ilgili olarak da "Öğretmenler bu görevlerini Türk Milli Eğitiminin amaçlarına ve temel ilkelerine uygun olarak ifa etmekle yükümlüdürler ve Öğretmenlik mesleğine hazırlık genel kültür, özel alan eğitimi ve pedagojik formasyon ile sağlanır" ifadeleriyle açıklık getirilmektedir. Yine aynı kanunun 45 maddesinde Öğretmenlerin, öğretmen yetiştiren yükseköğretim kurumlarından ve bunlara denkliği kabul edilen yurtdışı yükseköğretim kurumlarından mezun olanlar arasından, Milli Eğitim Bakanlığınca seçileceği ifadesiyle öğretmen yetiştiren kurumlar olarak Eğitim Fakülteleri işaret edilmektedir.

Burada Weber'in ifade ettiği uzmanlaşma ile 1739 sayılı MTK'da ifade edilen uzmanlaşma birbirinden farklılık göstermektedir. Weber (Balc1, 2003) kapitalist üretim biçiminde uzmanlaşmadan söz ederken 1739 sayılı MTK profesyonalizm anlamında öğretmenlik mesleğinde uzmanlaşmayı ifade etmektedir. Yani öğretmenlerin yalnızca eğitim fakültelerinde yetiştirilmesi gerektiği söylenebilir.

Fakat öğretmen yetiştirme sadece eğitim fakültesinden mezun öğrencilerle sınırlı kalmamaktadır. Formasyon uygulamasıyla diğer fakültelerden mezun olan bireyler de öğretmen olabilmektedir. 1997 tarihinde YÖK öğretmenlik sertifika programlarının uygulamadan uzak, içerik ve süre açısından yetersiz olduğunu ileri sürerek tezsiz yüksek lisans programlarını uygulamaya koymuştur. YÖK 2010 yılında aldığı kararla tezsiz yüksek lisans programları kaldırılarak yerine tekrar pedagojik formasyon eğitimini tekrar getirmiştir (Eraslan ve Çakıcı, 2011).

Pedagojik formasyon uygulamasına yönelik Eğitim Fakültelerini etkisizleştirdiği, eğitim sürelerinin azlığı nedeniyle niteliksiz mezunlar verdiği, üniversitelerin ekonomik kaygılarla 
kontenjanları yüksek tuttuğu, öğrencilerin para verdikleri için her durumda mezun olacaklarına yönelik inançları, yeterince atama bekleyen eğitim fakültesi mezunları olduğu gibi gerekçelerle eleştirilmektedir.

Bununla birlikte Şimşek (2015), meslek ve teknik liseler dahil çok çeşitli branşlarda öğretmen ihtiyacını tek başına eğitim fakültelerinin gidermesinin mümkün olmadığını, lise branş öğretmenlikleri konusunda Fen ve Edebiyat Fakülteleri kaynağının kullanılması gerektiğini, Pedagojik formasyon programlarının kalitesini artırmak amacıyla bu programları tezli veya tezsiz yüksek lisans programlarına dönüştürmenin de eğitim fakültesi mezunları açısından ciddi adaletsizlik yaratacağını söylemektedir.

Günümüzde eğitsel kurumlar yani eğitim fakülteleri toplum için yüksek derecede eğitilmiş uzmanlar yetiştirmektedir. Fakat bazı nedenlerle dönem dönem herhangi bir lisans mezununa birkaç aylık pedagojik formasyon eğitimi verilerek öğretmenlik mesleği yapma hakk1 tanınmaktadır. Bu durum, araştırmanın problem durumunu oluşturmaktadır.

Alanyazın incelendiğinde pedagojik formasyon alan öğrencilerin öğretmenlik mesleğine yönelik tutumlarını inceleyen çalışmalara (Polat, 2013; Eraslan ve Çakıcı, 2011; Kartal ve Afacan, 2012), pedagojik formasyon alan öğrencilerin farklı değişkenlere göre incelendiği çalışmalara (Demircioğlu ve Özdemir, 2014; Güneş ve Gökçek, 2012; Gömleksiz ve Fidan, 2011) ve pedagojik formasyonu eğitim sistemi sorunu olarak gören çalışmalara (Yıldırım ve Vural, 2014; Azar, 2011) rastlanmıştır. Bu araştırma, eğitim fakültesi öğrencileriyle pedagojik formasyon alan öğrencilerin sorulara verdikleri yanıtları karşılaştırmalı olarak ele alması ve sadece kuramsal bir çalışma olmaması nedeniyle önemlidir.

\section{Amaç}

$\mathrm{Bu}$ araştırma, Eğitim Fakültesi 1. ve 4. Sınıf öğrencileriyle pedagojik formasyon alan öğrencilerin öğretmenliğin uzmanlık gerektiren bir meslek olup olmadığına yönelik görüşlerini ortaya çıkarmayı amaçlamaktadır. Bu kapsamda aşağıdaki sorulara cevap aranmaktadır:

1. Eğitim Fakültesi 1.sınıf, 4.sınıf ve pedagojik formasyon öğrencilerinin öğretmenliğin uzmanlık gerektirip gerektirmediği konusundaki görüşleri nedir?

2. Eğitim Fakültesi 1.sınıf, 4.sınıf ve pedagojik formasyon öğrencilerinin Pedagojik formasyon alarak ya da almadan öğretmen olma konusundaki görüşleri nedir?

3. Eğitim Fakültesi 1.sınıf, 4.sınıf ve pedagojik formasyon öğrencilerinin alan dışı atanma konusundaki görüşleri nedir?

4. Eğitim Fakültesi 1.sınıf, 4.sınıf ve pedagojik formasyon öğrencilerinin Pedagojik formasyon alan bireylerin eğitim fakültesi mezunlarıyla aynı koşullarda atanma şansı olması konusundaki görüşleri nedir?

5. Eğitim Fakültesi 1.sınıf, 4.sınıf ve pedagojik formasyon öğrencilerinin pedagojik formasyonun öğretmen işsizliğine etkisi konusundaki görüşleri nedir?

\section{Yöntem}

$\mathrm{Bu}$ bölümde araştırma modeline, çalışma grubuna, veri toplama aracı, verilerin toplanması ve çözümlenmesine yer verilmiştir.

\section{Araştırmanin Modeli}

Bayburt Eğitim Fakültesi 1. ve 4. Sınıf öğrencileriyle 2014-2015 güz döneminde pedagojik formasyon alan öğrencilerin öğretmenliğin uzmanlık gerektirip gerektirmediği konusundaki görüşlerini ortaya çıkarmak için nitel araştırma yöntemlerinden olgubilim deseni kullanılmıştır. Nitel araştırmalar gözlem, görüşme ve belge çözümleme gibi nitel veri toplama yöntemlerinin kullanıldığı, algıların ve olayların doğal ortamda gerçekçi ve bütüncül bir biçimde ortaya konulmasına yönelik nitel bir sürecin izlendiği araştırmalardır (Yıldırım ve Şimşek, 2005). Olgubilim deseninde araştırmacı farkında olduğu ancak derinlemesine ve ayrıntılı anlayışa sahip olmadığg olgulara odaklanır (Yıldırım ve Şimşek, 2006). Bu araştırma yöntemi, bireylerin deneyimlerini tanımlamak ve yorumlamak için bireylerden deneyimlerini ödünç almaktadır (Jasper, 1994; Miller, 2003). Nitel bir araştırmanın fenomenoloji analizinde, bireysel ifadeler 
aracılığıyla bireylerin deneyimlerinden olgunun genel tanımı ortaya çıkartılmaya çalışılmaktadır (Patel, 2002; Baker, 1992). Aynı zamanda fenomenoloji analizinde, bireysel ve yaşanmış deneyimler ayrıntısıyla incelenmekte ve katılımcıların bireysel algılarını nasıl oluşturdukları açıklanmaktadır (Smith ve Eatough, 2007).

\section{Çalışma Grubu}

Araştırmanın çalışma grubunu, 2014-2015 öğretim yılında Bayburt Eğitim Fakültesi 1. (67) ve 4. Sınıf (75) öğrencileriyle yine bu dönemde pedagojik formasyon alan (75) öğrenciler oluşturmaktadır. Eğitim Fakültesi 1.sınıf öğrencileri öğretmenlik mesleğiyle yeni tanıştıkları için, 4.sınıf öğrencileri mezuniyete yaklaştıkları için ve formasyon öğrencileri de fakülte dış1 atamaya uygun oldukları için amaçlı örneklem yoluyla seçilmişlerdir. Aynı zamanda araştırmaya katılan öğrenciler kolay ulaşılabilir durum örneklemesi yoluyla tercih edilmişlerdir. Amaçlı örnekleme zengin bilgiye sahip olduğu düşünülen durumların derinlemesine çalışılmasına olanak vermektedir. Amaçlı örnekleme tekniklerinden, kolay ulaşılabilir durum örneklemesi araştırmaya hız ve pratiklik kazandırırken, araştırmacının yakın ve erişebilmesinin kolay olduğu bir durumu seçmesini sağlar (Karasar, 2010). Çalışma grubuna katılan Eğitim Fakültesi 1.sınıf öğrencileri Sınıf Öğretmenliği ve Rehberlik-Psikolojik Danışmanlık bölümü, Eğitim Fakültesi 4.sınıf öğrencileri Sınıf Öğretmenliği, Din Kültürü ve Ahlak Bilgisi Öğretmenliği bölümü, Pedagojik Formasyon öğrencileri Spor Yöneticiliği, Matematik, İşletme, İlahiyat, Türk Dili ve Edebiyatı, Sosyoloji, Gıda Mühendisliği bölümü öğrencileridir.

\section{Veri Toplama Aract}

Araştırmacılar tarafından öğrencilerin öznel değerlendirmelerini alabilmek için uzmanlaşma, pedagojik formasyon alarak öğretmen olma, öğretmen olabilme koşulları, alan dışı atanma konularıyla ilgili araştırma amaçlarını yordayan 9 sorudan oluşan bir görüşme formu hazırlanmıştır. Her soruda kapalı uçlu bir tercih sunulmuş, ardından açıklama yapabilecekleri sondalar eklenmiş̧ir. Kapsam geçerliliğini sağlayabilmek için uzman görüşleri alınmış (Eğitim Yönetimi Teftişi Ekonomisi ve Planlaması Bölümünden 1 doçent ve 1 yardımcı doçent, Temel Eğitim Bölümünden 1 yardımcı doçent ve 1 doktora öğrencisinden uzman görüşü alınmıştır) ve önerileri doğrultusunda görüşme formuna son şekli verilmiştir. Çalışma grubuna uygulama yapılmadan önce çalışma grubunda yer almayan 20 öğrenciye ön uygulama yapılmış, soruların anlaş1lır ve amaca yönelik olduğu görülmüştür.

\section{Verilerin Toplanmast}

Verilerin toplanması aşamasında görüşme formları elden dağıtılmış ve doldurulduktan sonra toplanmıştır. Öğrencilerin görüşme formlarını doldurmaları yaklaşık olarak 15 dakika ile 35 dakika arasında değişmiştir.

\section{Verilerin Çözümlenmesi}

Araştırmada görüşmelerden elde edilen nitel verilerin analizinde içerik analiz tekniği kullanılmıştır. Ayrıca sorulara verilen yanıtların yüzde ve frekansları da hesaplanmıştır. Görüşme formlarına öğrencilerin objektif ve gerçek görüşlerini yazabilmeleri için isimlerini yazmaları istenmemiştir. Toplanan görüşme formlarına kodlar verilmiştir. Eğitim Fakültesi 1. sinıf öğrencileri "öğrenci”, Eğitim Fakültesi 4. sınıf öğrencileri "aday” ve Pedagojik Formasyon öğrencileri "formasyon" kelimeleriyle isimlendirilmiştir.

Araştırmanın geçerlilik ve güvenirliği için Miles ve Huberman (1994) tarafından önerilen güvenirlik formülü kullanılmıştır. Öğrencilerin verdikleri yanıtlar iki araştırmacı tarafından incelenmiştir. İki araştırmacının oluşturduğu temalarda "görüş birliği" ve "görüş ayrılığı" olan konular karara bağlanmıştır. Buna göre Miles ve Huberman'ın (1994) önerdiği gibi; Güvenirlik = Görüş Birliği / (Görüş Birliği + Görüş Ayrıllı̆̆ $)$ formülünden yola çıkarak araştırmanın güvenirliği \% 88'dir. Miles ve Huberman'ın (1994) önerisine göre araştırma güvenilir kabul edilmiştir. 


\section{Bulgular}

Bayburt Eğitim Fakültesi 1. ve 4. Sinıf öğrencileriyle 2014-2015 güz döneminde pedagojik formasyon alan öğrencilere uzmanlaşma kavramına yönelik görüşleri sorulmuştur. Öğrencilerin uzmanlaşmaya çoğunlukla olumlu baktıkları görülmektedir. Tablo1'de bu dağılım görülmektedir.

Tablo 1. Uzmanlaşma kavramına yönelik görüşler

\begin{tabular}{lllll}
\hline Grup & Olumlu & \multicolumn{2}{l}{ Olumsuz } \\
& Frekans & Yüzde \% & Frekans & Yüzde \% \\
\hline Eğitim Fakültesi 1.sinıf & 64 & 95,5 & 2 & 3 \\
Eğitim Fakültesi 4.sinıf & 71 & 94,7 & 0 & 0 \\
Pedagojik Formasyon & 70 & 93,3 & 1 & 1,3 \\
\hline
\end{tabular}

Araştırmaya katılan öğrencilerin büyük çoğunluğunun (1.sınıf \% 95,5; 4.sınıf \% 94,7; Pedagojik Formasyon \% 93,3) uzmanlaşma kavramına olumlu baktıkları, gruplar arasında da değerlerin çok yakın olduğu görülmektedir. Öğrencilerin uzmanlaşma ile ilgili görüşlerinde en fazla tekrar edilen ifadelerin "bir konuda fazla bilgiye sahip olma, bir konuda gelişme ve eğitim alma, alanıyla ilgili bilgi ve becerilere sahip olma, bir alanda en iyi olma, yaptığı işi en iyi yapma, alanında başarılı ve verimli olma, yeterli düzeye ulaşma" olduğu görülmektedir. Ortak görüşü yansıtan öğrencilerden bazıları soruyu şöyle yanıtlamıştır:

Bir kişinin belli bir konuda gelişme ve bu doğrultuda iyi bir ĕgitim almasıdır. ögrenci65

Bir konu hakkında yeterli bilgiye, donanıma sahip olmasi gerekiyor. aday74

Kişinin istediği bir konuya yeterince hakim olabilmesi, o konu üzerinde kendini en üst düzeyde yetiştirmesi. formasyon 65

Öğrenciler uzmanlaşma kavramına çoğunlukla olumlu bakarken, öğretmenlik mesleğinin uzmanlık gerektirip gerektirmediği konusundaki düşüncelerini almak için sorulan sorunun yanıtlarına yönelik dağılım Tablo 2'de verilmektedir.

Tablo 2. Öğretmenlik mesleğinin uzmanlıkla ilişkisine yönelik görüşlerin dă̆ıllımı

\begin{tabular}{lllll}
\hline \multicolumn{1}{c}{ Grup } & $\begin{array}{l}\text { Evet } \\
\text { Frekans }\end{array}$ & Yüzde \% & Hayır \\
& Frekans & Yüzde \% \\
\hline Eğitim Fakültesi 1.sınıf & 67 & 100 & 0 & 0 \\
Eğitim Fakültesi 4.sınıf & 75 & 100 & 0 & 0 \\
Pedagojik Formasyon & 72 & 96 & 3 & 4 \\
\hline
\end{tabular}

Tablo 2'den de anlaşılacağı gibi Eğitim Fakültesi öğrencilerinin tamamı Pedagojik Formasyon öğrencilerinin de \% 96's1 öğretmenliğin uzmanlık gerektiren bir meslek olduğunu düşünmektedirler. Öğretmenlik mesleğinin uzmanlık gerektirdiğini ifade eden öğrencilerin en fazla tekrar ettikleri noktalar şöyledir: "neyi nasıl öğreteceğini bilmesi için, insan yetiştirmek kolay olmadığ 1 için, öğrenciye katkı sağlamak için, öğrencinin gelişimi için, kaliteyi ve verimi artırmak için, en iyisini (en iyi öğretmenliği) yapması için”. Öğretmenliğin uzmanlık gerektirmediğini ifade eden öğrenciler ise öğretmenliğin tecrübe ve gönüllülükle yapılacak bir iş olduğunu düşündüklerinden uzmanlığa gerek olmadığını söylemişlerdir. Öğrencilerden bazıları görüşlerini aşağıdaki gibi belirtmişlerdir:

Her önüne gelen ögrretmen olamaz çünkü. Belli bir lisans ĕgitimi alıp, mesleğinin ehli olmalı. ögrenci49

Ögrrencinin gelişimini bilmeyen bir ögrretmen uygun eğitim veremez. Stnıf yönetimi ve bunun gibi birçok kuralı bilmesi kaliteli eğitim için olması gerekenlerdir. aday5 
Çünkü daha çok gönül işidir, vicdan işidir. Gittiğim okullarda yani ücretli çalıştığım okullarda bu durumun farkina vardım. formasyon 12

Öğrencilere Eğitim Fakültesi mezunu olmayan diğer fakülte mezunlarının pedagojik formasyon almadan öğretmen olarak atanması konusundaki görüşleri sorulmuştur. Üç gruptaki öğrencilerin de büyük kısmı bu durumu olumsuz olarak değerlendirmişlerdir. Bu bulgular Tablo 3'de görülmektedir.

Tablo 3. Eğitim fakültesi mezunu olmayan birinin formasyon almadan ögretmen olarak atanmasına yönelik görü̈şlerin dăğllım

\begin{tabular}{lllll}
\hline Grup & Olumlu & & Olumsuz \\
& Frekans & Yüzde \% & Frekans & Yüzde \% \\
\hline Eğitim Fakültesi 1.sınıf & 0 & 0 & 67 & 100 \\
Eğitim Fakültesi 4.sınıf & 1 & 1,3 & 73 & 97,3 \\
Pedagojik Formasyon & 4 & 5,3 & 71 & 94,7 \\
\hline
\end{tabular}

Öğrencilerin büyük kısmı öğretmenliğin uzmanlık gerektiren bir meslek olduğunu düşündükleri için ve pedagojik formasyon uzmanlaşma anlamına geldiği için öğrencilerin yine büyük çoğunluğu (1.sınıf \%100; 4.sınıf \%97,3; Pedagojik Formasyon \%94,7) pedagojik formasyon olmadan atanmayı uygun görmemiştir. Öğrencilerin en fazla tekrar ettikleri ifadelerin "öğretmenlik bilgisi olmadan öğretmenlik olmaz, eğitim fakültesi öğrencilerine haksızlık/adaletsizlik olur, öğrencinin halinden anlayamaz, gerekli eğitimi almamış olur, formasyon öğretmenliğin olmazsa olmazı" şeklinde olduğu görülmektedir. Öğrenci görüşlerinden bazıları şöyledir:

Başkasının hakkını çalmış ve de bunun (öğretmenliğin) ĕgitimini almamıştır. Madem eğitim alamadan ögretmen olarak atanıyorsa o zaman Eğitim Fakültesinin ne yararı var? aday 74

Çünkü eğitim derslerini boşuna almıyoruz bizler. Özellikle de eğitim derslerinde çocukların gelişim özelliklerini ögrenerek onlara hangi yaşta nasıl davranmamız gerektiğini ögreniyoruz. Materyal tasarımı ile bunu destekliyoruz... aday38

Öğrenciye nasıl bir yöntemle yaklaşılacă̆ düşünülürse formasyonsuz olmaz. Hatta formasyon eğitimi 6 ayda verilmemeli. Çok kapsamlı bir eğitim. formasyon 15

Öğrencilere eğitim fakültesi dışında başka bir fakülteden mezun olmuş bireylerin pedagojik formasyon alarak öğretmen olması konusunda ne düşündükleri sorulmuştur. Öğrencilerin verdikleri yanıtların dağılımı Tablo 4'de verilmektedir.

Tablo 4. Farkl fakültelerden mezun birinin formasyon alarak ögretmen olmasina yönelik görüșlerin dağılımı

\begin{tabular}{lllll}
\hline Grup & Olumlu & & \multicolumn{2}{c}{ Olumsuz } \\
& Frekans & Yüzde \% & Frekans & Yüzde \% \\
\hline Eğitim Fakültesi 1.sınıf & 4 & 6 & 62 & 92,5 \\
Eğitim Fakültesi 4.sınıf & 9 & 12 & 65 & 86,7 \\
Pedagojik Formasyon & 55 & 73,3 & 18 & 24 \\
\hline
\end{tabular}

Tablo 4'de de görüldüğü gibi gruplar arasında büyük bir fark görülmektedir. Eğitim Fakültesi 1.ve 4. Sınıf öğrencileri Pedagojik formasyon alarak öğretmen olmaya olumsuz bakarken (1. sinıf \% 92,5; 4. sınıf \% 86,7); Pedagojik Formasyon alan öğrenciler olumlu (\% $73,3)$ bakmaktadır. Eğitim fakültesi öğrencileri formasyon almanın öğretmenlik için yeterli olmadığını açıklarken en fazla tekrar ettikleri ifadeler şunlar olmuştur: "farklı fakültelerde öğrencinin yetiştiriliş amacı farklı, birkaç ayda alınan eğitim yeterli değil, formasyon niteliksiz, 
formasyonun amacı farklı, eğitim fakültesinde okuyan öğrencilere haksılılı, bu şekilde ögrretmen olursa verim düşük olur.” Öğrenciler şu sözlerle düşüncelerini aktarmışlardır:

Formasyon bence işsiz üniversite mezunlarına iş bulabilmek için uydurulmuş bir durum. bir de üniversitelerin gelir kaynağı. aday73

Günümüzde formasyon almak, Nasrettin Hoca'nın-Parayı veren düdüğ̈̈ çalar-misali olduğundan, alsin almasin fark etmez. aday 17

Bu durum ögretmenliğe verilen değerin düşmesine yol açar, ögretmenlik kutsaldır. Bir emek vardır. Formasyonla ögretmen olunmaz. ögrenci40

Pedagojik Formasyon alan öğrencilerden formasyon alarak öğretmen olmaya olumsuz bakan \% 24'lük kısım eğitim fakültesi öğrencileriyle benzer ifadelerde bulunmuşlardır fakat olumlu görenler en fazla "formasyon alarak eğitimimizi tamamlıyoruz, eğitim dersleri aynı, eğitim fakültesi lisans öğrencileri de yeterli değil” gibi ifadeleri kullanmışlardır. Öğrencilerden bazılarının açıklamaları şunlardır:

Kendi alanında kendini yetiştirmiş ise formasyon ile de bu eğitimi süslemişse öğretmen olabilir. PF52

Kişisel gelişim ve ögretmenlik, liderlik vasıfları bulunan kişi için formasyon bir formalitedir fakat aksi özellikleri taşıyan kişi için formasyon olsa da olmasa da değişen bir şey yoktur. formasyon 9

Şimdiki eğitim fakültesindeki lisansın da öğretmenlik için yeterli olmadığını görüyorum. O zaman diyorum ki formasyon da yeterli olabilir. formasyon 7

Öğrencilere mezun oldukları branş dışında farklı bir branştan öğretmenin başka bir branşa atanması konusundaki görüşleri sorulmuştur. Öğrencilerin yanıtlarının dağılımı Tablo 5 'de verilmiştir.

Tablo 5. Öğretmen adaylarının mezun olunan branş dışındaki farklı bir branşa ögretmen olarak atanmalarına iliş̧kin görüşleri

\begin{tabular}{lllll}
\hline Grup & Olumlu & & Olumsuz \\
& Frekans & Yüzde \% & Frekans & Yüzde \% \\
\hline Eğitim Fakültesi 1.sınıf & 1 & 1,5 & 66 & 98,5 \\
Eğitim Fakültesi 4.sınıf & 0 & 0 & 75 & 100 \\
Pedagojik Formasyon & 3 & 4 & 72 & 96 \\
\hline
\end{tabular}

Öğrencilerin büyük çoğunluğunun (1.sınıf \% 98,5; 4.sınıf \% 100; Pedagojik Formasyon \% 96) birinin bitirdiği branş haricinde başka bir branşa atanmasını olumsuz gördükleri görülmektedir. Öğrenciler görüşlerini açıklarken sıklıkla "kişi diğer branşta yeterli bilgiye sahip değil, verimli olmaz, öğrencilerin gelişimine katkısı olmaz, o branşta uzmanlığ uygun değil" gibi ifadeler kullanmışlardır. Aşağıda bu yaygın görüşlerden bazılarını öğrenciler şöyle dile getirmiştir:

Çünkü her branş farklı özellikler gerektirir. Bir matematik ögrretmeninin anaokulu ögretmeni olarak atanmasının o öğrenciye nasıl bir faydası olabilir ki? Her branş kendi dalının özelliklerini, ě̆itimini alır sonuçta. öğrenci4

Her öğretmen kendi alanında uzmandır. Başka bir alana atandiğı zaman birçok eksiği olacaktır ve ögrencilerin ögretmene bakış açısı da değişecektir. formasyon32

Herhangi birinin bitirdiği branş haricinde başka bir branşa atanmasını büyük oranda olumsuz gören öğrencilere kendilerinin bitirdikleri bölüm dışında başka bir bölüme daha atanma 
hakk1 verilse tercihlerinin ne olacağı sorulmuştur. Öğrencilerin kendileri söz konusu olduğunda görüşlerinde farklılık olduğu görülmektedir. Bu dağılım Tablo 6'da verilmiştir.

Eğitim Fakültesi 1.sınıf öğrencilerinin \% 98,5'i farklı bir branşa atanmayı uygun görmezken, kendilerine atanma hakk1 verilse \% 18' kullanmak istediğini söylemiştir. Eğitim Fakültesi 4.sınıf öğrencilerinin tamamı başka branşa atanmayı uygun görmezken kendilerine bu hak verildiğinde \% 26,7'si kullanmak istediğini ifade etmiştir. Aradaki farkın en büyük olduğu Pedagojik Formasyon grubundaki öğrencilerin ise \% 96's1 uygun bulmazken, kendilerine hak verildiğinde \% 36's1 kullanmak istemektedir. Öğrenciler bu hakk1 kullanmak isteme nedenlerini açılarken sıklıkla "bana uygun başka bölümlerde var, başka bölüm okumak istiyordum, geleceğim için" gibi ifadeler kullanmışlardır. 1.sınıf öğrencileri daha çok bölümünden memnun olmadığ 1 için bu alternatifi kullanmak isterken, 4.sınıf ve pedagojik formasyon öğrencileri işsizlik için tercih etmişlerdir. Kendilerini şu sözlerle ifade etmişlerdir:

Bu ülkede iş bulmak çok zor, bulduğun yeri kaçırmayacaksın. aday62

Hangisi iyi ise onu tercih ederdim. formasyon 35

Tablo 6. Öğrencilerin bitirdiği bölüm dışında başka bir bölüme daha atanma hakkı konusundaki görüşlerinin dağılımı

\begin{tabular}{lllll}
\hline Grup & Evet & & Hayır \\
& Frekans & Yüzde \% & Frekans & Yüzde \% \\
\hline Eğitim Fakültesi 1.sinıf & 12 & 18 & 54 & 80,6 \\
Eğitim Fakültesi 4.sinıf & 20 & 26,7 & 55 & 73,3 \\
Pedagojik Formasyon & 27 & 36 & 48 & 64 \\
\hline
\end{tabular}

Başka bölüme atanma hakkını kullanmak istemeyen öğrenciler özellikle eğitim fakültesinde çoğunluktadır (Tablo 6). Bu öğrenciler ise "eğitimimi aldığım bölümde başarılı olurum, bilgim az olacağı için istemem, verimli olmaz, kimsenin hakkını yemek istemem" gibi ifadeler kullanmışlardır. Bu öğrencilerden bazılarının ifadeleri şöyledir:

Nasıl ben Sosyoloji ya da Felsefe bitirenlerin rehber ögretmen olarak atanmasını istemiyorsam benim için de bu durum geçerli olacaktır. Bu nedenle istemezdim. ögrenci38

Sinıf Öğretmenlĭgi alanında kendimi yetiştirdiğimden diğer bir alanda çalışmak istemem. Bilmediğim bir şeyi yapmak sağlıklı olmaz. aday63

Öğrencilerin cevaplarını farklılaştıran diğer bir soru da kendi bölümlerinde atanma olmazsa ve başka bir bölüme atanma hakkı verilirse kullanmalarıyla ilgilidir. Bu konuyla ilgili öğrenci yanıtlarının dağılımı Tablo 7'de verilmiştir.

Tablo 7. Öğrencilerin Kendi bölümünde atama olmadı̆ğnda başka bir bölüme atama hakkı ile ilgili görüşleri

\begin{tabular}{lllll}
\hline Grup & Evet & & Hayır & \\
& Frekans & Yüzde \% & Frekans & Yüzde \% \\
\hline Eğitim Fakültesi 1.sınıf & 26 & 38,8 & 41 & 61,2 \\
Eğitim Fakültesi 4.sınıf & 31 & 41,3 & 44 & 58,7 \\
Pedagojik Formasyon & 41 & 54,7 & 32 & 42,7 \\
\hline
\end{tabular}

Tablo 7'den de anlaşılacağı gibi öğrencilerden bu hakkı kullanmak isteyenlerin sayısı oldukça artmıştır. Özellikle Pedagojik Formasyon öğrencilerinin yarıdan fazlası (\% 54,7) bu hakkı kullanacaklarını ifade etmişlerdir. Eğitim Fakültesi öğrencilerinin sayıları birbirine çok yakındır (1.sınıf \% 38.8; 4.sınıf \% 41,3). Öğrenciler bu hakkı kullanma isteme nedenlerini açıklarken "işsizlik, başka çare olmadığından, çalışmam gerekiyor, ekonomik nedenler" gibi ifadeler kullanmışlardır. Bu tercihin doğru olmadığını ama ekonomik nedenlerin onları bu 
tercihe yönelttiği görülmektedir. Öğrencilerin yine büyük kısmı da bu hakkı kullanmak istemediklerini ifade etmişlerdir. Onların açıklamalarında da sıklıkla "uzmanlaştığım alan dışında faydalı olmaz, bilmediğim alanda başarılı olamam ve hak yemek istemem" ifadeleri görülmektedir. Öğrencilerden bazılarının sözleri şunlardır:

Hayatımı devam ettirmek zorundayım. Maalesef bu sorularda düşünceler değil, mecburiyetler devreye giriyor. aday 4

Şu an formasyon alma nedenimdir. Gıda mühendisi olarak atanmamız çok zor. formasyon 7

Öğrencilere pedagojik formasyon alan bireylerin eğitim fakültesi mezunlarıla aynı koşullarda yarışmasını nasıl değerlendirdikleri sorulmuştur. Öğrencilerin bu soruya verdikleri yanıtların dağılımı Tablo 8'de verilmiştir.

Tablo 8. Formasyon alarak öğretmenlik hakkı kazanan bireylerin ĕgitim fakültesi mezunlarıyla aynı koşullarda yarışmasına (ya da atama şansı olmasını) yönelik görüşler

\begin{tabular}{lllll}
\hline Grup & Olumlu & \multicolumn{3}{c}{ Olumsuz } \\
& Frekans & Yüzde \% & Frekans & Yüzde \% \\
\hline Eğitim Fakültesi 1.sınıf & 2 & 3 & 64 & 95,5 \\
Eğitim Fakültesi 4.sınıf & 8 & 10,7 & 64 & 85,3 \\
Pedagojik Formasyon & 58 & 77,3 & 12 & 16 \\
\hline
\end{tabular}

Eğitim Fakültesi öğrencilerinin büyük kısmı (1.sınıf \% 95,5; 4.sınıf \% 85,3) Pedagojik Formasyon alan öğrencilerin eğitim fakültesi mezunlarıyla aynı koşullarda yarışmasını olumsuz görürken; Pedagojik Formasyon alan öğrencilerin büyük kısmı (\% 77,3)olumlu görmektedir. Eğitim fakültesi öğrencileri olumsuz görme nedenleri açıklarken sıklıkla " hakkımıza giriyorlar, hakkımızı yiyorlar, eğitim fakültesinin başarısı gibi olmaz, eğitimleri niteliksiz, eğitim süreleri az, eğitim fakültesini kazanmak zor diğerlerini kazanmak kolay, eğitim fakültesi mezunu ile formasyon alan nitelik olarak aynı olmaz" ifadelerini kullanırken; Pedagojik Formasyon alan öğrenciler olumlu görme nedenlerini "hak eden kazansın, formasyon öğretmenlik vasfı kazandırıyor, formasyonla eğitim fakültesinin aynı derslerini alıyoruz, kriterleri sağlayan öğretmenliği hak eder, bizim eğitimimiz daha iyi, KPSS'de başarılı olan atanır" ifadeleriyle açıklamışlardır. Öğrenciler kendilerini şu sözlerle açıklamaktadırlar:

Bizim gibi ĕgitim fakültesini kazanmak için çalışıp duran insanların haklarının yendiğini düşünüyorum. aday29

Formasyon sadece birkaç aylık eğitimle olacak bir şey değil. 4 yıllık ĕgitimin yeterli olmadığını düşünürken 6 aylık eğitimin hiç yeterli olmadığını düşünüyorum. aday67

O kişiler eğitim fakültesinde okumadan atansalar, eğitim fakültesinde okuyan boşuna okumuş olacak. Öyle olunca o da gider başka bir bölüm okur, formasyon alır, ögretmen olur. aday 20

Adaletli değil, formasyon alan ögrencinin bilgisiyle fakülte mezunu arasinda dağlar kadar fark vardır. Hatta atanabilmeleri söz konusu edilmemelidir. öğrenci57

Sonuç olarak her ikisinde de öğretmenlik eğitimi veriliyor, öğretmenler arası rekabet artar, kaliteli ögretmenler çoğalır. formasyon 57

Fen - edebiyata öncelik verilmeli. Çünkü daha ă̆ır ve iyi bir eğitim alıyoruz. formasyon 62

Araştırmaya katılan öğrencilere Pedagojik formasyon alan öğrencilerin öğretmen işsizliği üzerine etkisi konusundaki düşünceleri sorulmuştur. Bu soruya verilen yanıtlar Tablo 9'da verilmiştir. 
Farklı Öğretmenlik Programına Devam Eden Öğretmen Adaylarının Öğretmenlik Mesleğine

Tablo 9. Pedagojik formasyon alan ögrrencilerin ögretmen işsizliğine etkilerine yönelik görüşler

\begin{tabular}{lllll}
\hline Grup & $\begin{array}{l}\text { Evet } \\
\text { Frekans }\end{array}$ & Yüzde \% & $\begin{array}{l}\text { Hayır } \\
\text { Frekans }\end{array}$ & Yüzde \% \\
\hline Eğitim Fakültesi 1.sınıf & 66 & 98,5 & 1 & 1,5 \\
Eğitim Fakültesi 4.sınıf & 69 & 92 & 4 & 5,3 \\
Pedagojik Formasyon & 47 & 62,7 & 27 & 36 \\
\hline
\end{tabular}

Tablo 9'da da görüldüğü gibi eğitim fakültesindeki öğrencilerin büyük kısmı (1.sınıf \% 98,5; 4.sınıf \% 92) Pedagojik Formasyon alan öğrencilerin de yarıdan fazlası (\% 62,7) formasyon alan öğrencilerin öğretmen işsizliğini etkilediğini düşünmektedir. Bu öğrencilerin sıklıkla "atama bekleyen öğretmen adaylarının sayısını artırdığı" ifadesini kullandıkları görülmektedir. Öğretmen işsizliğini etkilemediğini düşünen öğrencilerin çoğunluğu açıklama yapmamıştır. Öğrenciler düşüncelerini şu sözlerle açıklamışlardır:

Belirli bir eğitimden geçmeden uzman olmadan öğretmen olunmaya çalışılırsa atamalar azaldı ̆̆ için öğretmen işsizliğini etkiler. ögrenci41

Daha çok talep olacak ve yapılan sinavlarda iyi olan yerleşecek. Hangi fakülteden mezun olunduğu farketmeyecek. aday62

Elbette etkiliyor. Her yıl sinava giren ve kaçta kaçının atandiğını görüyoruz. formasyon 72

\section{Tartışma / Sonuç ve Öneriler}

Türkiye'de, daha önce kamusal hizmet olarak sayılan tüm alanlarda piyasalaşma yaşanırken bunun başlıca yansımalarından biri emek süreçlerinde olmaktadır. Buna paralel olarak, eğitim sistemi özelinde son yıllarda daha görünür hale gelen neoliberal politika ve uygulamaları, eğitimci emeğini dönüşüme uğratarak öğretmenlerin önemli bir bölümünü ücretli emekçiye çevirmiştir. Esasen eğitim sisteminin tüm bileşenlerinin, kamusaldan özele, kolektiften bireysele doğru tarihsel dönüşümlere maruz kaldığ bu süreçte, eğitimin anlamı da kökten bir değişime uğramaktadır (Demirer, 2012).

Esnek üretim örgütlenmesi işgöreni içinde bulunduğu toplumsal sınıfin bağlarından uzaklaştırarak ve güvencesiz çalışma koşulları altında yalnızlaştırarak güçsüz bireylere dönüştürmektedir (Ünal, 2008).

Araştırmaya katılan öğrenciler uzmanlaşmayı olumlu karşılarken, öğretmenlik mesleğinin bir uzmanlık alanı olduğunu ifade etmektedirler. 1739 sayılı Milli Eğitim Temel Kanunu da "Öğretmenlik bir uzmanlık mesleğidir" diyerek bu düşünceyi doğrulamaktadır. Bu nedenle pedagoji eğitimi alınmadan öğretmen olarak atanmanın doğru olmadığını düşünmektedirler. Eğitim fakültesi öğrencileri farklı fakültelerden mezun olanların öğretmen olarak atanmasına karşı çıkarken pedagojik formasyon öğrencileri doğal olarak bu eğitimi aldıktan sonra öğretmen olarak atanmanın doğru olduğunu düşünmektedirler.

Öğrenciler, 1739 sayılı Milli Eğitim Temel Kanununda da belirtildiği gibi Pedagojik formasyonu öğretmenlik mesleğinde uzmanlaşma için ön koşul olarak görmektedirler. Eğitim Fakültesinde öğrenim gören öğrenciler dört yıllık eğitim süresine yayılmış, çeşitli ve kapsamlı olarak pedagojik formasyonu alırken; diğer fakültelerden mezun olan öğrenciler dokuz dersi altı ay gibi kısa sürede alarak bu ön koşulu sağlamaktadır. Milli Eğitim Bakanlığı bir yandan öğretmenlerin nitelikli yetiştirilmesi amacıyla özellikle öğretmen yeterliklerinin belirlenmesine yönelik bir çok çalışma gerçekleştirirken; öte yandan da açılan bu pedagojik formasyon sertifika eğitimi programları ile isteyen herkese, belirlenen öğretmen yeterliklerini göz ard1 ederek öğretmenlik yolunu açmaktadır. Böylelikle oluşan bu ikilem, nitelikli öğretmen yetiştirme konusunda kamuoyunda çok ciddi endişeler yaratmaktadır (Azar, 2011).

Eğitim fakültelerinin birkaç aylık sürelerle pedagojik formasyon eğitimi vermeleri, bunun karşılığında maddi talepte bulunmaları farklı fakülte mezunu öğrenciler tarafından formasyonun satın alınması şeklinde algılanmaktadır ki bu da pedagojik formasyonu ticarileştirmektedir. Gorz'un da ifade ettiği gibi bilginin değişim değeri yaratacak nitelikte 
olması, onun bir piyasasının olması ya da piyasanın yaratılmasıla olanaklıdır. Piyasa oluştuğunda, üniversite içinde üretilen bilgi metalaşmış demektir. Bir malı kullanım değeri için değil de piyasada satmak için ürettiğiniz andan itibaren her şey değişir. $\mathrm{O}$ zaman, maliyeti azaltmak verimliliği artırmak için sürekli olarak hesap yapmayı öğrenmek zorundasınız (Gorz, 1995). Piyasanın her alana girmesine paralel olarak, eğitimin çeşitli biçimlerdeki meta formlarının yerleşik hale gelmesi, öğrenci ve aileleri müşteri, öğretmenleri ise satıcı konumuna doğru itmektedir (Demirer, 2012).

Öğretmen adayları kendi branşları dışında farklı bir branşa atanmanın doğru olmadığını ifade ederken öğretmen işsizliğinin artması nedeniyle mezun oldukları alanlar dışında farklı bir alana atanma seçeneği sunulursa değerlendireceklerini ve atanmayı isteyeceklerini ifade etmektedirler.

1990'lardan bu yana “diplomalı işsizlik" giderek artmakta olup, eşitsiz toplumların eşitsizliğine dair temel bir sosyal yaraya, kapitalist piyasacı iktisadi yapılanmanın aşamadığı bir sistem yarasına dönüşmektedir. Bu yaradan muzdarip diplomalı işsizlerin önemli bir grubunu da atanmayan öğretmenler oluşturmaktadır (Gümüş ve Çetin, 2012)

Eğitim fakültesi öğrencileri pedagojik formasyon alan üniversite mezunlarıyla eşit koşullarda atanmalarının doğru olmadığını, pedagojik formasyon programının aynı zamanda öğretmen işsizliğini artıran önemli bir neden olduğunu ve eğitim fakültesi mezunlarına haksızlık yapıldığını düşünmektedirler.

Eraslan (2004) çalışmasında KPSS gibi sınavlarda test tekniğine sahip olan bireylerin başarılı olduğunu, böylece bireylerin yaratıc1lıları, becerileri vb. özelliklerinin geri planda kaldığını ifade etmiştir. Ayrıca gözden kaçan bir durumunda 1739 sayılı Milli Eğitim Temel Kanununda belirtilen bir öğretmende bulunması gereken niteliklerin ölçülmemesidir. Araştırma sonuçlarına göre Öğretmen adayları öğretmen atamalarında fakülteye giriş puanı, mezuniyet derecesi gibi değişkenlerin de dikkate alınmasını istemektedirler. Öğretmen adayları KPSS öğretmen seçiminde ideal bir yöntem olduğuna inanmamaktadır. Öğretmen adayları KPSS'nin eğitim bilimleri bilgi düzeyini ölçecek nitelikte olmadığını belirtmiş̧lerdir. KPSS'de sadece bilişsel becerilerin ölçülmesi öğretmenlik mesleğine seçilmek için yeterli değildir. Öğretmen adayları kendilerini öğretmenlik mesleğine değil, KPSS'ye hazırlamakta olduklarını düşünmektedirler. Toker Gökçe (2014) araştırmasında ise aday öğretmenlerin atanamama ve işsiz olma nedeni olarak katılımcıların çoğunun, yapılan genel sınavlar ve yöneticilerin adaletli olmaması ve siyasi bağlantılarının olmamasından dolayı atanamadığını düşündüğünü ortaya koymuştur.

Sonuç olarak hem eğitim fakültesi öğrencileri hem de pedagojik formasyon alan öğrenciler öğretmenlik mesleğinin uzmanlaşma gerektirdiğini düşünmektedirler. Fakat işsizlik gibi nedenlerle başka fakültelerden mezun olan bireylerin kısa süreli pedagojik formasyon alarak öğretmen olmaları eğitim fakültelerini etkisizleştirmekte aynı zamanda ülke eğitim sistemine uzun sürede olumsuz etkilere neden olacağı; ayrıca üniversitelerin pedagojik formasyon eğitimi vermeleri bilginin metalaşması anlamında üniversiteler üzerinde olumsuz etkilere yol açacağı düşünülmektedir.

\section{Kaynaklar}

Azar, A. (2011). Türkiye'deki öğretmen eğitimi üzerine bir söylem: nitelik mi, nicelik mi? Yüksekögretim ve Bilim Dergisi, 1, 36-38.

Balcı, A. (2003). Eğitim örgütlerine yeni bakış açıları: Kuram-araştırma ilişkisi. Kuram ve Uygulamada Ë̆itim Yönetimi, 33(1), 26-61

Bursalığlu, Z. (1982). Okul yönetiminde yeni yapı ve davranış, Ankara: A.Ü. Basımevi.

Dalton, R., Dan, W.D., Todor, W.J., Spendoloni, G.J., Fielding, L.W., \& Porter (1980). Organization structure and performance: a critical review, The Academy of Management Review, 5(2), 49-64.

Duman, A. (1988). Türk eğitim sisteminde uzman ve uzmanlık sorunu. Eğitim ve Bilim, 12(69). 
Demircioğlu, E. ve Özdemir, M. (2014). Pedagojik formasyon öğrencilerinin çok kültürlü eğitime yönelik tutumlarının bazı değişkenlere göre incelenmesi. Ege Üniversitesi Ĕ̈itim Fakültesi Dergisi, 1(15), 211-232.

Demirer, D. (2012). Eğitimde piyasalaşma ve öğretmen emeğinde dönüşüm. Çalışma ve Toplum, 32, 167-186.

Eraslan, L. ve Çakıcı, D. (2011). Pedagojik formasyon programı öğrencilerinin öğretmenlik mesleğine yönelik tutumları. Kastamonu Ĕ̈itim Fakültesi Dergisi, 19(2), 427-438

Eraslan, L. (2004), Öğretmenlik mesleğine girişte kamu personeli seçme sınavı (kpss) yönteminin değerlendirilmesi. Uluslararası İnsan Bilimleri Dergisi, 1(1), 1-31.

Ercan, F. (2002). Yeni YOK yasa taslağı üzerine: yol ayrımındaki Türkiye'nin kurumsallaşan sermayesi. Üniversite ve Toplum Dergisi,2 (2), http://www.universite-toplum.org/ text.php3?id=75? ref=paylasimturkey.biz

Gorz, A. (1995). İktisadî aklın eleştirisi (Çev. Işık Ergüden). İstanbul: Ayrıntı Yayınları.

Gömleksiz, M.N. ve Fidan, E.K. (2011). Pedagojik formasyon programı öğrencilerinin web pedagojik içerik bilgisine ilişsin öz -yeterlik alg1 düzeyleri. Turkish Studies, 6(4), 593620.

Gümüş, A. ve Çetin, İ. (2012). Öğretmen işsizliği ve dershane öğretmenliği: atanan ve atanmayan öğretmenlerin uyarlanma biçimleri. Eleştirel Pedagoji, 4, 2-34.

Güneş, G. ve Gökçek, T. (2012). Pedagojik formasyon öğrencilerinin öğrenme stilleri. Ĕgitim ve Öğretim Araştırmaları Dergisi, 1 (4), 28-40.

Gwartney J.D., \& Stroup, R.L. (2004). Temel ekonomi. (Çeviri: Yıldıray Arslan). İstanbul: Liberte Yayınları.

Gorz, A. (1995). İktisadî aklın eleştirisi (Çev. Işık Ergüden). İstanbul: Ayrıntı Yayınları.

Hage, J. (1965). An axiomatictheory of organizations. Administrative Science Quarterly, 10(3), 289-320.

Jasper, M.A. (1994). Issues in phenomenology for researchers of nursing. Journal of Advanced Nursing, 19, 309-314.

Karasar, N. (2010). Bilimsel araştırma yöntemi. Ankara: Nobel Yayıncılık.

Kartal, T. ve Afacan, Ö. (2012). Pedagojik formasyon eğitimi alan öğretmen adaylarının öğretmenlik mesleğine ilişkin tutumlarının incelenmesi. Mehmet Akif Ersoy Üniversitesi Ĕ̌itim Fakültesi Dergisi, 12(24), 76-96.

Miller, S. (2003). Analysis of phenomenological data generated with children as research participants. Nurse Researcher, 10(4), 68-82.

Miles, M.B., \& Huberman, A.M. (1994). Qualitative data analysis (2nd edition). Thousand Oaks, CA: Sage Publications.

Patel, R.M. (2002). Phenomenoloji: History, its methodological assumptions and application. mini-dissertation. Unpublished master dissertation, Rand Afrikaans University.

Milli Eğitim Temel Kanunu. 1739 SY. (1973). Resmi Gazete. Sayı: 14574. 4/6/1973.

Polat, S. (2013). Pedagojik formasyon sertifika programı ve eğitim fakültesi öğrencilerinin öğretmenlik mesleğine yönelik tutumlarının incelenmesi, e-international journal of educational research, 4(2), http://dergipark.ulakbim.gov.tr/ijer/ article/view /1073 000292/0.

Robbins, S.P. (1983). Organization theory: The structure and design of organizations, N.J. PrenticeHall.

Smith, J.A., \& Eatough, V. (2007). Interpretative phenomenological analysis, in lyons E. \& Coyle, A. Analysing Qualitative Data in Psychology, pp: 35-64, London: Sage.

Sucu, Y. (2000). Geçmişten günümüze yönetim düşüncesindeki gelişmeler: bütünleştirici bir durumsallık modeli. Ankara: Elit Yayınc1lık.

Şeker, Ş.E. (2014). Max Weber ve bürokrasi, Ybs Ansiklopedisi. 10 Temmuz 2015 tarihinde http://ybsansiklopedi.com/wp-content/uploads/2014/10/m11_p25 27 maxweber veburokrasi1.pdf. adresinden alınmıştır. 
Şimşek, H. (2015). Pedagojik formasyon enstitüsü, 10 Temmuz 2015 tarihinde http:// www.hasansimsek.net/files/PEDAGOJ\%C4\%B0K\%20FORMASYON\%20ENST\%C 4\%B0T\%C3\%9CS\%C3\%9C.pdf. adresinden alınmıştır.

TDK- Türk Dil Kurumu. (2015). Uzmanlaşma. 10.07.2015 tarihinde http://tdk.gov.tr/index.php?Option=com.bts\&arama=kelime\&guid=TDK.GTS. 55a4f2 e36fd4f6.24030499, adresinden alınmıştır.

Toker Gökçe, A. (2014). Atanamama nedeniyle farklı bir mesleğe yönelen işsiz aday öğretmenler üzerine bir çalışma. Akademik Sosyal Araştırmalar Dergisi, 2(1), 191208.

Ünal, L.I. (2008). Neoliberalizm, esnek istihdam ve kadın öğretmenler: kavramsal bir çerçeve”, eğitim ve bilim işkolunda çalışan kadınların sosyal haklart ve iş güvencesi (Ed. Elif Akgül Ateş ve Handan Çağlayan) Ankara: Eğitim-Sen Yayınları. Temmuz, 97-106.

Yıldırım I., Vural, Ö.F. (2014). Türkiye'de öğretmen yetiştirme ve pedagojik formasyon sorunu. Journal of Teacher Education and Educators, 3(1), 73-90.

Yıldırım, A. ve Şimşek, H.(2006). Sosyal bilimlerde nitel araştırma yöntemleri. Ankara: Seçkin.

\section{Extended Abstract}

\section{Introduction}

Current study was designed with phenomenological method of qualitative research methods, which aims to reveal the perspectives of 1st and 4th year students of Education Faculty and pedagogical training students on whether teaching profession requires expertise. Qualitative research methods were used to reveal participants' views on whether teaching profession requires expertise. The data were collected in 2014-2015 fall term. Qualitative research is a research in which observation, interviews and document analysis are used, additionally a qualitative process is followed to put forward perceptions and events with realistic and integrated manner in natural environment (Yıldırım and Şimşek, 2005). In phenomenological method, researcher focuses on the fact that he/she is aware of but has no in-depth and detailed understanding about.

\section{Method}

The research method borrows individuals' experiences to describe and interpret their experiences (Jasper, 1994; Miller, 2003). In phenomenological analysis of a qualitative research, general description of a pattern is tried with individual expressions of experiences (Patel, 2002; Baker, 1992).

The study group consists of 1st year students (67) and 4th year students (75) of Bayburt Education Faculty, and pedagogical training students (75) in 2014-2015 academic years. Purposeful sampling was used because 1st year students has met teaching profession recently, 4th year students will graduate and pedagogical training students were selected as they are suitable for appointment. At the same time, participants were selected by availability sampling. Purposeful sampling is to allow in-depth study of the conditions which are considered as wealth of information.

Descriptive analysis technique was used to analyse qualitative data which were obtained from interviews. Additionally, percentage and frequency of responses were calculated. New names were given to the collected interview forms.

\section{Result and Discussion}

Students express that they have positive views about specialization and teaching profession is an expertise. It is seen that majority of the participants have positive views about specialization and the value between groups is very close (1st year students, $95.5 \%$, 4th year students, $94.7 \%$, pedagogical formation students, $93.3 \%$ ). Some repeated phrases are; "to have more information on a subject, development and education on a subject, to have knowledge and skills about the 
field, to be the best in the field, to do the job in a best way, to be effective in the field, to be successful and efficient and to achieve a sufficient level". All of the students at the Faculty of Education and $96 \%$ percent of Pedagogical Formation students believe that teaching profession requires expertise. They declare that teaching profession requires expertise.

As most of the students thought that teaching profession requires expertise and pedagogical formation means specialization, students thought that appointment without pedagogical training is not appropriate (1st year students, $100 \%$; 4th year students, $97.3 \%$; pedagogical formation students, 94.7\%). While ducation faculty students have negative views about being teacher with pedagogical formation (1st year students, $92.5 \%$, 4th year students, $86.7 \%$ ), pedagogical formation students have positive views $(73.3 \%)$.

The majority of students think that someone's appointment to another teaching major except from his graduation major is not appropriate (1st year students, $98.5 \%$; 4th year students, $100 \%$; pedagogical formation students, $96 \%$ ). While 1st year students of the Faculty of Education have negative views about appointment to another major $(98.5 \%)$, they said that if they had right they would use it $(18 \%)$. While 4th year students of the Faculty of Education have negative views about appointment to another major, they said that if they had right they would use it (26,7\%). While 1st year students and 4th year students (1st year students, 95,5\%, 4th year students, $85,3 \%$ ) think that being in the same conditions with pedagogical formation students in terms of appointment is not appropriate, majority of the pedagogical formation students think positively (77,3\%). Majority of the education faculty students (1st year students, $98,5 \%$, 4th year students, $92 \%$ ) and more than half of the pedagogical formation students $(62,7$ $\%)$ think that formation effects teacher unemployment.

National Education Basic Law No. 1739 confirms the idea that "Teaching is an occupation which requires expertise". Therefore, they believe that appointment as a teacher without pedagogical training is not appropriate. As education faculty students object to appointment of other faculties' graduate as teacher, pedagogical formation students think that it is appropriate after they have completed the training. While Faculty of Education students have studied educational formation as varied and comprehensive in four-year training period; students who have graduated from other faculties have nine courses in six months. Ministry of Education has carried out lots of project to train qualified teachers, especially to determine teacher competencies; on the other hand, Ministry of Education provides opportunity to be teacher with pedagogical training programs and certification ignoring the designated teacher qualification. 